\title{
Hypertension and Autonomic Control
}

\author{
Natália Turri da Silva*, Thais Roque Giacon, Franciele Marques Vanderlei, Ana Laura Ricci Vitor, Carlos Marcelo Pastre, \\ Luiz Carlos Marques Vanderlei
}

\begin{abstract}
Physiotherapy Department, Faculdade de Ciências e Tecnologia da UNESP - FCT/UNESP, Presidente Prudente, Brazil
*Corresponding author: natalia.turri@hotmail.com
\end{abstract}

Received February 01, 2014; Revised April 17, 2014; Accepted April 28, 2014

\begin{abstract}
Arterial hypertension is considered one of the most important public health problems and had their development, progression and complications associated with the autonomic nervous system (ANS). In this context, the present systematic review aim at gathering recent studies (2003-2013) that addressed the relation between ANS and hypertension, in order to update the knowledge in the last 10 years. Searches were made onMedLine / PubMed, PEDro, SciELO, IBECS, COCHRAINE and LILACS databases using the intersection between the keywords "hypertension", "autonomic nervous system", "sympathetic nervous system ", "parasympathetic nervous system " and "heart rate variability". A total of 17 articles were included and main findings of this review indicating the acute influence of the ANS in different types of hypertension characterized by a reduction of the overall heart rate variability (HRV) and a reduction in the parasympathetic component of ANS evaluated by linear indexes. In addition, the behavior of the sympathetic component could present an increase or a reduction according to the study design. Thus further studies to assess the influence of chronic influence of ANS on hypertension as well as investigations by nonlinear HRV indexes are needed.
\end{abstract}

Keywords: hypertension, autonomic nervous system, sympathetic nervous system, parasympathetic nervous system

Cite This Article: Natália Turri da Silva, Thais Roque Giacon, Franciele Marques Vanderlei, Ana Laura Ricci Vitor, Carlos Marcelo Pastre, and Luiz Carlos Marques Vanderlei, "Hypertension and Autonomic Control." American Journal of Medical Sciences and Medicine, vol. 2, no. 2 (2014): 48-53. doi: 10.12691/ajmsm-2-2-5.

\section{Introduction}

The arterial hypertension (AH) has a multifactorial nature, defined as constants high levels of blood pressure [1,2] and presented in one in three adults worldwide [3], had their development, progression and complications associated with the autonomic nervous system (ANS) once the enhanced sympathetic activation is essential for the comprehension of human hypertension pathophysiology $[3,4,5,6]$.

The increment of muscle sympathetic nerve activity as well as the augmented cardiac and renal noradrenalin release from the sympathetic nerves is a feature in patients with essential hypertension [3]. The sympathetic activation, a branch of autonomic control reaching about 20\% to $30 \%$ of essential hypertension [7] and is evident even in very low risk subjects with high-normal blood pressure. Additionally, the resting sympathetic excitation may precede overt $\mathrm{AH}$ [3].

One method of assessing the ANS is by the heart rate variability (HRV), an investigative resource that informs the system situation. In general HRV describes the oscillations between consecutive hearts beat intervals (RR) that are related with the influences of ANS on sinus node $[8,9]$. Considering the changes on HRV pattern offering a sensitive and advance indicator of health impairments [10], the interest from the perspective of hypertension is still greater. Additionally the $\mathrm{AH}$ is related with functional and structural alterations [2] of several organs as heart, brain, kidneys and blood vessels and considered as a risk factor to the development of clinical manifestations of atherosclerosis, that increase the probability of cardiac incidents (ischemic heart disease, sudden death and general mortality), placing the importance of controlling the related factors as a matter of public health [11].

In this context the present study aim at gathering recent studies that addressed the relation between ANS and hypertension in order to better understand the influence of ANS on the $\mathrm{AH}$ and provide an update of knowledge in the last 10 years.

\section{Methods}

\subsection{Search Strategy and Selection}

The revision were made between March 2013 and April 2013 on Medical Literature Analysis and Retrieval System Online (MedLine/Pubmed), Physiotherapy Evidence Database (PEDro), Scientific Electronic Library Online (SciELO), Spanish Bibliographic Index of Health Sciences (IBECS), Cochraine Library and Latin American and Caribbean Literature on Health Sciences (LILACS) databases.

The keywords were chosen in advance by the Health Sciences Descriptors (DeCS) and their corresponding in English - Medical Subject Headings (MeSH). The keyword "hypertension" combined with the keyword 
"autonomic nervous system", "sympathetic nervous system”, "parasympathetic nervous system” were used as well as to the non-descriptor but keyword of this study "heart rate variability".

\subsection{Inclusion Criteria}

The revision included studies with human samples from the period 2003 to 2013 in Portuguese, Spanish and English, that addressed hypertension and autonomic control jointly, under resting conditions, that used the heart rate variability to assess autonomic nervous system and it had theirs full texts available. All types of study design were included.

\subsection{Exclusion Criteria}

The exclusion of studies was based on those with editorial format, who described the medicine intervention on autonomic nervous system and whose focuses were not population basis.

\subsection{Selection Strategy}

Firstly all the studies were submitted on a title selection, according to the inclusion criteria established. For this, the title should express as focus of the study the following aspects: the autonomic analysis in hypertensive individuals, the hypertension influence on autonomic nervous system, the hypertension consequences on cardiovascular modulation and those related to hypertension or some information concerning this framework, such as high blood pressure, high systolic or diastolic pressure increased with the words parasympathetic and / or sympathetic nervous system.

In sequence, the results were filtered to identify repetitions due to the use of several databases. The titles chosen have their abstract read in order to select the articles that dealt specifically HRV in hypertensive individuals.

Subsequently, when the abstracts discoursed about the subject discussed, theirs complete articles were totally read. Furthermore, the references of the selection studies were revised in order to complementary the search. All senior reviewer who judged about the articles inclusion.

\subsection{Date Analysis}

The data analyzed by a qualitative form and tabulated in accordance to the authors and year of the study, description of the population, protocol used, studied variables and outcomes. It was used the executive summary for selected articles that had no full version available.

\section{Results}

The results had a total of 17 articles included. Initially 2941 items were found among all the databases listed (Medline, Lilacs, Pubmed, Ibecs, Cocrhane e Pedro) with the pre intersections established by the descriptors. All articles were listed on a Microsoft Excel spread sheet and after discard the repetitions among the databases, 112 articles were remained.

Among the 112 articles, just 25 were used HRV as autonomic nervous system tool and had their texts read integrally. After reading the texts, remained 17 articles, because five were not included due to the stipulated languages (English, Spanish or Portuguese), one, because the non-inclusion of hypertensive individuals diagnosed and two, non-population base studies.

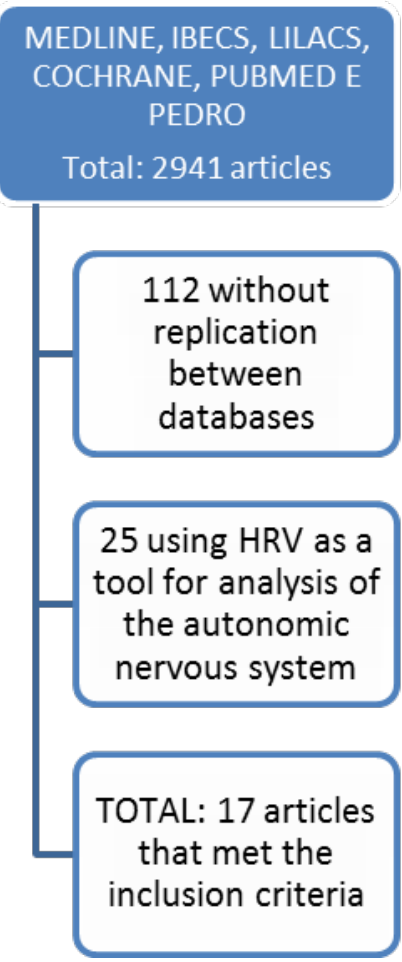

Figure 1. Chart that summarizes the search strategy and selection

Selected articles were organized into tables containing the following items: author / year, population, methods / indexes and conclusions, being divided into two groups according to their nature. In the first group of articles, the authors compared the ANS action in normotension and different types of hypertension describes as following normotension and essential hypertension [12,13,14,15]; normotension, essential hypertension and white coat hypertension [16,17]; normotension and recent hypertension [18]; normotension, essential hypertension and recent hypertension [19], hypertension associated or not associated with left ventricular dysfunction and normotension [20], white coat hypertension, masked hypertension and hypertension sustained [21], in recent hypertension and normotension [22] (Table 1).

The second group consists of articles assessing the ANS under different influences, such as time [23], circadian rhythm [24], age and posture [25], QT interval [26], awake state and sleep [27], menopause [28] (Table 2).

\section{Discussion}

The review's main findings the acute influence of the ANS in different types of hypertension, indicating a reduction in overall HRV [12,13,14,19,22,23] evaluated by linear indexes and including present on primary hypertension in the adolescent period [27].

About the reduction of global variability, Çelik et $\mathrm{al}^{14}$ discussed the association with a inflammatory process present in hypertensive individuals, indicated in the study by the high values of the $\mathrm{C}$ - reative protein. 
Table 1. Articles about the autonomic nervous system comparing normotension and different types of hypertension, organized in chronological order

\begin{tabular}{|c|c|c|c|}
\hline AUTHOR/YEAR & POPULATION & METHODS/INDEXES & CONCLUSIONS \\
\hline $\begin{array}{l}\text { Virtanen et al., } \\
2003 \text { [12] }\end{array}$ & $\begin{array}{l}\text { Normotension }(\mathrm{n}=105) \text { and hypertension } \\
(\mathrm{n}=191) \text { of both gender between } 34 \text { to } 54 \\
\text { years old without therapy for } \mathrm{AH} \text {. }\end{array}$ & $\begin{array}{l}5 \text { min at rest in supine position / } \\
\text { Indexes: RMSSD, SDNN, HF, LF e } \\
\text { VLF. }\end{array}$ & $\begin{array}{l}\text { Hypertensive showed less value of } \\
\text { SDNN and RMSSD. }\end{array}$ \\
\hline $\begin{array}{l}\text { Ruediger et al., } \\
2003 \text { [13] }\end{array}$ & $\begin{array}{l}\text { Normotension ( } \mathrm{n}=20) \text { and hypertension men } \\
\quad(\mathrm{n}=20) \text { between } 19 \text { to } 42 \text { years old. }\end{array}$ & $\begin{array}{c}\text { Comparison between spontaneous } \\
\text { breath in rest period and mental stress / } \\
\text { Indexes: linear on time and frequency } \\
\text { domain. }\end{array}$ & $\begin{array}{l}\text { On frequency domain, at rest the } \\
\text { hypertensive showed HF reduction and } \\
\text { at mental stress a LF increment, } \\
\text { compared with normotensive. } \\
\text { On temporal domain, the RR mean } \\
\text { increased in both groups at mental stress } \\
\text { when compared with rest and } \\
\text { hypertensive showed less values of RR } \\
\text { mean and HR, compared with } \\
\text { normotension. } \\
\end{array}$ \\
\hline $\begin{array}{l}\text { Neumann et al., } \\
2005 \text { [16] }\end{array}$ & $\begin{array}{l}\text { Normotension ( } \mathrm{n}=40) \text {, hypertension }(\mathrm{n}=40) \\
\text { and white coat hypertension }(\mathrm{n}=40) \text { men } \\
\text { between } 40 \text { to } 70 \text { years without therapy at } \\
\text { least } 2 \text { months or already receipt treatment to } \\
\text { AH in the past. }\end{array}$ & $\begin{array}{l}\text { At least } 6 \text { min of ECG recording at rest } \\
\text { (the position was not specified) / } \\
\text { Indexes: linear on time and frequency } \\
\text { domain (LF, HF e LF/HF). }\end{array}$ & $\begin{array}{l}\text { Hypertension and white coat } \\
\text { hypertension showed parasympathetic } \\
\text { reduction. Additionally, hypertensive } \\
\text { showed less values of HF and LF and } \\
\text { significant increment of LF/HF when } \\
\text { compared to normotensive. }\end{array}$ \\
\hline $\begin{array}{l}\text { Prakash et al., } \\
2005 \text { [19] }\end{array}$ & $\begin{array}{l}3 \text { groups of comparison, } 15 \mathrm{M} \text { and } 10 \mathrm{~W} \text { each: } \\
\text { normotension with } 48 \pm 12 \text { years, recent } \\
\text { hypertension without therapy with } 50 \pm 12 \\
\text { years and individuals with high-normal } \\
\text { pressure (130-139/85-89mmHg) and } 46 \pm 13 \\
\text { years. } \\
\end{array}$ & $\begin{array}{l}\text { Comparison between } 5 \text { min of HRV } \\
\text { record at rest in supine and standing / } \\
\text { Indexes: linear on time (SDNN) and } \\
\text { frequency domain (LF, HF). }\end{array}$ & $\begin{array}{l}\text { Hypertensive showed less value of LF, } \\
\text { HF e SDNN and a reduction of HRV } \\
\text { with the postural change. Individuals } \\
\text { with high-normal pressure showed an } \\
\text { increment of LF. }\end{array}$ \\
\hline $\begin{array}{l}\text { Piccirillo et al., } \\
2006 \text { [20] }\end{array}$ & $\begin{array}{l}3 \text { groups of comparison between } 51 \text { to } 57 \\
\text { years old of both gender: normotension } \\
(n=29) \text {, hypertension }(n=60) \text { with LVD or } \\
\text { without LVD. }\end{array}$ & $\begin{array}{l}30 \text { min at lying rest ( } 15 \text { breath by min - } \\
\text { controlling by metronome) and } 15 \text { min } \\
\text { after tilt test / Indexes: linear on } \\
\text { frequency domain (LF, HF, VLF). }\end{array}$ & $\begin{array}{l}\text { Both groups of hypertension (with LVD } \\
\text { or without LVD) showed higher values } \\
\text { of LF (ms and nu) compared with } \\
\text { normotension. Hypertensive with LVD } \\
\text { showed higher values of LF after tilt test } \\
\text { then the other groups. }\end{array}$ \\
\hline $\begin{array}{c}\text { Fagard et al., } 2007 \\
{[21]}\end{array}$ & $\begin{array}{l}\text { Masked hypertension, white coat } \\
\text { hypertension and sustained hypertension } \\
\text { ( } \mathrm{n}=1379 \text { ) of both gender between } 24 \text { to } 59 \\
\text { years old. }\end{array}$ & $\begin{array}{l}\text { Comparison between } 15 \text { min of HRV } \\
\text { record at rest in supine and } 15 \text { min on } \\
\text { free-standing / Indexes: linear on } \\
\text { frequency domain (LF e HF). }\end{array}$ & $\begin{array}{l}\text { White coat hypertension showed a } \\
\text { sympathetic increment and a } \\
\text { parasympathetic reduction compared } \\
\text { with the other groups. Masked } \\
\text { hypertension and sustained hypertension } \\
\text { showed a normal autonomic modulation } \\
\text { although this showed less value of HF. }\end{array}$ \\
\hline $\begin{array}{l}\text { Madsen et al., } \\
2008 \text { [17] }\end{array}$ & $\begin{array}{c}3 \text { groups of comparison between } 30 \text { to } 80 \\
\text { years old of both gender: essential } \\
\text { hypertension (BP }>140 / 90 \text { ), white coat } \\
\text { hypertension (PA }>140 \text { for systolic and / or } \\
90 \mathrm{mmHg} \text { in repeated measurements and daily } \\
\text { ambulatory BP }<135 / 85 \mathrm{mmHg} \text { ) and } \\
\text { normotension }(\mathrm{BP}<135 / 85 \mathrm{mmHg} \text { ). }\end{array}$ & $\begin{array}{l}\text { Comparison between } 30 \text { min of HRV } \\
\text { record at rest in supine, } 10 \text { min standing } \\
\text { after change position, } 10 \text { min at rest in } \\
\text { standing and with control of breath ( } 2 \\
\text { min with more than } 20 \text { incursions by } \\
\text { min) / Indexes: linear on frequency } \\
\text { domain. }\end{array}$ & $\begin{array}{l}\text { The control of breath caused a reduction } \\
\text { on LF and LF/HF in all groups. In } \\
\text { hypertensive, the LF reduction was less } \\
\text { evident. No difference was found on } \\
\text { HRV records of white coat hypertension } \\
\text { or normotension. }\end{array}$ \\
\hline $\begin{array}{l}\text { Pavithran et al., } \\
2008 \text { [18] }\end{array}$ & $\begin{array}{l}\text { Normotension }(\mathrm{n}=14 \mathrm{M}) \text { of } 40 \pm 9 \text { years old and } \\
\text { recent hypertension }(\mathrm{n}=36 \mathrm{M}) \text { of } 44 \pm 9 \text { years } \\
\text { old. }\end{array}$ & $\begin{array}{l}5 \text { min of HRV record at rest with deep } \\
\text { breath. Additionally, oxidative stress } \\
\text { variable was collected: } \\
\text { malondialdehyde and total antioxidant } \\
\text { status / Indexes: linear on time and } \\
\text { frequency domain. } \\
\end{array}$ & $\begin{array}{l}\text { Hypertensive showed a reduction of } \\
\text { HRV and an increment of oxidative } \\
\text { stress. During deep breath, hypertensive } \\
\text { showed less value of SDNN, RRtri, } \\
\text { RMSSD, LF e HF indexes than } \\
\text { normotensive. }\end{array}$ \\
\hline $\begin{array}{l}\text { Pavithran et al., } \\
2008 \text { [22] }\end{array}$ & $\begin{array}{l}\text { Normotension }(\mathrm{n}=17 \mathrm{M}) \text {, with }(111 \pm 7 / 71 \pm 5 \\
\text { mmHg) and } 39 \pm 7 \text { mean of years old and } \\
\text { recent hypertension }(\mathrm{n}=35 \mathrm{M}) \text { with }(155 \\
\pm 17 / 101 \pm 8 \mathrm{mmHg}) \text { without therapy. }\end{array}$ & $\begin{array}{l}5 \text { min of HRV record at rest in supine, } \\
\text { BP measured in the last of rest in } \\
\text { supine and immediately after getting up } \\
\text { (until } 2 \text { min) and again at the last } 5^{\text {th }} \\
\text { min in standing. / Indexes: linear on } \\
\text { time and frequency domain. }\end{array}$ & $\begin{array}{l}\text { Hypertensive showed a significantly } \\
\text { lower in HRV when comparing with } \\
\text { normotensive. Differences in mean RR } \\
\text { values were insignificant. Hypertensive } \\
\text { showed a lower HF in supine position. } \\
\text { There was a decrease of short-term HRV } \\
\text { in recent hypertension. } \\
\end{array}$ \\
\hline $\begin{array}{l}\text { Çelik A et al., } \\
2012 \text { [14] }\end{array}$ & $\begin{array}{l}\text { Healthy volunteers }(\mathrm{n}=34) \text { with } 58 \pm 11 \text { years } \\
\text { old, being } 18 \mathrm{M} \text {; and hypertension }(\mathrm{n}=121) \\
\text { with } 59 \pm 11 \text { years old, being } 60 \mathrm{M} \text {. }\end{array}$ & $\begin{array}{l}24 \text { hours of HRV record and the high } \\
\text { sensibility of C-reactive protein was } \\
\text { analyzed. / Indexes: linear on time } \\
\text { domain. }\end{array}$ & $\begin{array}{l}\text { Hypertensive showed a reduction of } \\
\text { HRV and increment at mean of C- } \\
\text { reactive protein. The authors suggest. } \\
\text { There is an inflammation in hypertensive } \\
\text { and is related to the imbalance of cardiac } \\
\text { autonomic functions. }\end{array}$ \\
\hline $\begin{array}{c}\text { Bajkó et al., } 2012 \\
\text { [15] }\end{array}$ & $\begin{array}{l}\text { Hypertension (n=86), with } 43 \pm 10 \text {, being } 44 \mathrm{M} \\
\text { without therapy; and normotension ( } \mathrm{n}=98) \text {, } \\
\text { with } 44 \pm 9 \text {, being } 50 \mathrm{M} \text { with therapy. }\end{array}$ & $\begin{array}{l}10 \text { min of HRV record in the morning } \\
\text { at rest supine and } 10 \text { min with } 70^{\circ} \text { of } \\
\text { passive tilt test. / Indexes: linear on } \\
\text { frequency domain. }\end{array}$ & $\begin{array}{l}\text { Hypertensive showed a reduction of LF } \\
\text { during passive tilt test, with significance } \\
\text { in supine. }\end{array}$ \\
\hline
\end{tabular}

Legend: $\mathrm{n}=$ number of subjects analyzed; $\mathrm{AH}=$ arterial hypertension; $\mathrm{BP}=$ blood pressure; $\mathrm{ECG}=$ electrocardiogram; $\mathrm{HF}=$ high frequency component; $\mathrm{HR}=$ heart rate; $\mathrm{HRV}=$ heart rate variability; LF=low frequency component; LF/HF=ratio of components of low and high frequency; LVD=left ventricular dysfunction, $\mathrm{M}=$ men ; $\mathrm{mmHg}=$ millimeters of mercury; $\mathrm{min}=$ =minutes; ms=milliseconds; $\mathrm{nu}=$ normalized unit; RMSSD=root mean square of differences between adjacent normal RR intervals; RR= interval between consecutives heart beat; RRtri=triangular index; SDNN=standard deviation of all normal RR intervals recorded in a time interval; tilt test $=$ xam that evaluates the behavior of heart rate and blood pressure in response to a change in body posture; VLF=very low frequency component; W=women. Source: Research data. 
Table 2. Articles about the autonomic nervous system evaluation related with the time, circadian rhythm, posture and age, QT interval, awake state and sleep, menopause, organized in chronological order

\begin{tabular}{|c|c|c|c|}
\hline AUTHOR/YEAR & POPULATION & METHODS/INDEXES & CONCLUSIONS \\
\hline $\begin{array}{l}\text { Schroeder et al., } \\
2003 \text { [23] }\end{array}$ & $\begin{array}{c}\text { Hypertensive and no hypertensive } \\
\text { ( } \mathrm{n}=11061 \text { ) of both gender between } 45 \\
\text { to } 54 \text { years old at baseline. }\end{array}$ & $\begin{array}{l}\text { Two evaluations with } 9 \text { years apart. } \\
\text { Evaluations from } 2^{\text {nd }} \text { to } 6^{\text {th }} \text { min at rest } \\
\text { in supine each one. / Indexes: linear } \\
\text { on time (mean of RR, RMSSD, } \\
\text { SDNN) and frequency domain. }\end{array}$ & $\begin{array}{c}\text { Hypertensive showed a reduction of HRV } \\
\text { and no hypertensive with a reduction of } \\
\text { HRV showed predisposition to develop AH } \\
\text { in } 9 \text { years. ANS is involved on AH } \\
\text { developing. }\end{array}$ \\
\hline $\begin{array}{l}\text { Takagi et al., } 2006 \\
\text { [24] }\end{array}$ & $\begin{array}{l}\text { Hypertensive ( } \mathrm{n}=82 \text { ) of both gender } \\
\text { with } 57 \pm 12 \text { years old, divided in } 4 \\
\text { groups according to percentage fall of } \\
\text { night SBP. }\end{array}$ & $\begin{array}{l}24 \text { hours of HRV record. / Indexes: } \\
\text { linear on frequency domain (HF e } \\
\text { LF/HF) }\end{array}$ & $\begin{array}{l}\text { In the morning, before standing, the } \\
\text { activation of the sympathetic branch plays } \\
\text { an important role in high blood pressure. }\end{array}$ \\
\hline $\begin{array}{l}\text { Karas et al., } 2008 \\
\text { [25] }\end{array}$ & $\begin{array}{c}\text { No treated hypertension of light or } \\
\text { moderate level (DBP between } 90 \text { to } \\
110 \mathrm{mmHg} \text { ) with } 18 \text { to } 74 \text { years old } \\
\text { were divided by age on }<60 \text { years } \\
(n=57) \text { and }>60 \text { years }(n=32) .\end{array}$ & $\begin{array}{l}20 \text { min of HRV record in supine and } \\
10 \text { min standing. / Indexes: linear on } \\
\text { frequency domain. }\end{array}$ & $\begin{array}{c}\text { The individuals with age }>60 \text { years } \\
\text { showed LF and HF value less }<60 \text { years. } \\
\text { Additionally, in standing had LF increment } \\
\text { and HF reduction. }\end{array}$ \\
\hline $\begin{array}{l}\text { Maule et al., } 2008 \\
\text { [26] }\end{array}$ & $\begin{array}{l}\text { No treated essential hypertension } \\
\text { (n=250) with prolonged QT ou } \\
\text { without. Individuals with drug } \\
\text { therapy and with cardiovascular } \\
\text { diseases were excluded. }\end{array}$ & $\begin{array}{l}24 \text { hours of HRV record. / Indexes: } \\
\text { linear on frequency and time domain. }\end{array}$ & $\begin{array}{l}\text { Indices of HRV in the time domain } \\
\text { (SDNN, RMSSD and pNN50) were } \\
\text { significantly reduced in patients with } \\
\text { prolonged QT compared with normal QT } \\
\text { indicating greater risk for developing } \\
\text { cardiovascular diseases. }\end{array}$ \\
\hline $\begin{array}{l}\text { Havlíceková et al., } \\
2009 \text { [27] }\end{array}$ & $\begin{array}{l}\text { Primary hypertension }(\mathrm{n}=22) \text { being } \\
\text { 5W and 17M with age between } 14 \text { to } \\
19 \text { years old and healthy young } \\
\qquad(\mathrm{n}=22) .\end{array}$ & $\begin{array}{l}24 \text { hours of HRV record. Analysis } \\
\text { realized under conditions of awake } \\
\text { state and sleep. / Indexes: linear on } \\
\text { frequency domain. }\end{array}$ & $\begin{array}{c}\text { Hypertensive adolescents had lower HF } \\
\text { and higher LF and LF/HF in awake state. } \\
\text { During sleep had lower HF and greater } \\
\text { LF/HF. Adolescents with primary } \\
\text { hypertension have impairments in } \\
\text { autonomic regulation during the day and } \\
\text { during the night. }\end{array}$ \\
\hline $\begin{array}{l}\text { Czarnecka et al., } \\
2009 \text { [28] }\end{array}$ & $\begin{array}{c}\text { Primary hypertension ( } \mathrm{n}=112 \text { ) being } \\
\text { W with age between } 45 \text { to } 55 \text { years } \\
\text { old were divided in two groups: post- } \\
\text { menopausal and } \mathrm{W} \text { with regular } \\
\text { menstrual cycle }\end{array}$ & $\begin{array}{l}24 \text { hours of HRV record. Drug } \\
\text { treatment pressure was suspended } \\
\text { four weeks before the study period. } \\
\text { / Indexes: linear on frequency } \\
\text { domain. }\end{array}$ & $\begin{array}{l}\text { After menopause, low values of VLF, HF, } \\
\text { LF and LF / HF were found. Increment of } \\
\text { sympathetic activity in postmenopausal W } \\
\text { may suggest a greater involvement in the } \\
\text { pathogenesis of hypertension. }\end{array}$ \\
\hline
\end{tabular}

Legend: AH=arterial hypertension; ANS=autonomic nervous system; DBP=diastolic blood pressure; ECG=electrocardiogram; HF=high frequency component; HRV=heart rate variability; $\mathrm{LF}=$ low frequency component; $\mathrm{LF} / \mathrm{HF}=$ ratio of components of low and high frequency; $\mathrm{M=men;} \mathrm{min=minutes;}$ mmHg=millimeters of mercury; ms=milliseconds; $n=$ number of subjects analyzed; pNN50=percent of differences between adjacent normal to normal intervals > 50 milliseconds; RR=interval between consecutives heart beat; RMSSD=root-mean square of differences between adjacent normal RR intervals in a time interval; SBP=systolic blood pressure; SDNN=standard deviation of all normal RR intervals recorded in a time interval; VLF=very low frequency; W = women. Source: Research data.

Different results were found regarding the behavior of the sympathetic nervous system (SNS). There isn't a consented about the answers obtained by the HRV index analysed (LF, VLF) that can be occurred due to the use of different evaluation protocols of evaluation involving changing positions, permanence in different positions of rest(supine or standing) and evaluation in autonomic tests.

BajkóZoltán et al [15]; Neumann et al [16], Prakash et al [19], e Karas $M$ et al [25] indicated lower simpathetic acting in hypertensive individuals when evaluated in rest and absoluted units of potence, however in the white coat hypertension was observed an increase in this component independing the rest position - supine or standing [21]; as well as along the day and in awake state in adolescents with a primary hypertension [27]; in hypertensive with or without the left ventricular dysfunction as in supine rest as post tilt test [20] and in decubit changes since rest to standing rest [25].

For intervention about this simpathetic increase Madsen et al [17] showed the respiratory control is able to reduce your action independent the kind of hypertension being the respiratory control a form to intervent on vagal balance.

In general the studies of Virtanen et al [12]; Neumann et al [16]; Prakash et al [19]; Piccirillo et al [20], Fagard RH [21]; Pavithran P [22]; Karas M et al [25] have demonstrated reduction in parassimpathetic nervous system, related by Pavithran et al [22] a lower parassimpathetic action in supine position.

Concerning this aspect Neuman et al [16] e Fagard et al [21] showed a decrease on parassimpathetic action together to simpathetic increase in white coat hypertensives.

Just one study ilustrated the cronic influence of the ANS in arterial hypertension, when did two evaluation, 9 years of interval between them, in more than 11 hundred individuals and showed further the reduction on HRV in hypertensive, pre disposition to arterial hypertension in normotensive individuals, but with low HRV in 9 years, sugaring the ANS is involved on development of arterial hypertension [23].

In general, the texts analysis in this revision indicated the HVR indexes commonly used to analyze hypertension are obtained by linear method at time and frequency domains, which can be related with already wide knowledge about this analyses type.

Referring to the hypertension characterization was observed that the studies published on the last 10 years have addressed it in different aspects such it pre hypertension, systemic arterial hypertension and whitecoat hypertension, with the included subjects in each group according to previously established scientific nomenclatures.

An important highlight is the different methods of capturing HRV. Portable instruments such as heart monitors, electrocardiograms and new analysis tools were employed illustrating the possibility of multiple signal acquisition. Furthermore, it was observed in the analysis of the articles that the recommendation not to consume substances that could interfere with the autonomic balance was not always described, which may have influenced the autonomic behavior in some studies. 
In relation to the participant population, the age of hypertensive individuals analyzed was in majority above 30 years old, being adolescent and infant population little explored. In this revision just Havlíceková [27] did an analysis of autonomic behavior in front of view the hypertensive in adolescent population, between 14 to 19 years old. Still regarding the participant population, a great variation at sampling number can be considered, including studies since 22 [27] until 11061 individuals [22].

The studies selected for this review were developed in Hungary [15], Italy [20,26], Slovakia [27], India [18,19,22], Canada [25], Japan [24], Germany [13], Denmark [17], Poland [28], Finland [12], Belgium [21], Pennsylvania [23] and Turkey [14]. There was a European predominance concerning studies involving assessment of autonomic modulation in hypertensive patients.

The mainly aspects of this revision pointed to a acute influence of the autonomic nervous system in different kinds of arterial hypertension caracterized by a decrease in global variability and parassimpathetic component of autonomic nervous system elauated by linear índex. Furthermore, the sympathetic behavior reveal as an increase or decrease according the studies. In this context, more studies about the cronic influence on ANS are necessary and the exploration by non linear index.

It is strongly clarified that hypertension promotes an autonomic imbalance, engendering difficult of adaptation to minimum stress conditions, as physical as mental. This imbalance between SNS and PNS contributes to installation of diseases in different corporal system, mainly attacking the cardiovascular health [10,30,31]. Something to be considered is the non-linear behavior of $\mathrm{RR}$ intervals. In order to implement the knowledge about the autonomic nervous system behavior in hypertensive individuals, new studies must be done using this type of analysis.

\section{Acknowledgement}

To Laboratory of physiologist of stress

\section{Statement of Competing Interests}

There was no conflict of interest.

\section{References}

[1] Ferreira JS, Aydos RD. "Prevalência da hipertensão arterial emcrianças e adolescentes obesos”. Ciência\& Saúde Coletiva.2010; 15(1): 97-104.

[2] Sociedade Brasileira de Cardiologia / Sociedade Brasileira de Hipertensão / Sociedade Brasileira de Nefrologia. "VI Diretrizes Brasileiras de Hipertensão”. ArqBrasCardiol 2010; 95(1 supl.1): $1-51$.

[3] Passos VMA, Assis TD, Barreto SM. "Hipertensão arterial no Brasil: estimativa de prevalência a partir de estudos de base populacional.” Epidemiologia e Serviços de Saúde. 2006; 15(1): 35-45.

[4] Rabetti AC, Freitas SFT. "Avaliação das ações em hipertensão arterial sistêmica na atenção básica”. Rev Saúde Pública. 2011; 45(2): 258-68.

[5] Costa JMBS, Silva MRF, Carvalho EF. “Avaliação da implantação da atenção à hipertensão arterial pelas equipes de
Saúde da Família do município do Recife (PE, Brasil)”. Ciência \& Saúde Coletiva. 2011; 16(2): 623-633.

[6] Schmidt MI, Duncan BB, Hoffmann JF, Moura L, Malta DC, Carvalho RMSV. "Prevalência de diabetes e hipertensão no Brasil baseada em inquérito de morbidadeauto-referida”, Brasil, 2006. Rev Saúde Pública.2009; 43(Supl 2): 74-82.

[7] Nogueira D, Faerstein E, Coeli CM, Chor D, Lopes CS, Werneck GL. "Reconhecimento, tratamento e controle da hipertensão arterial: Estudo Pró-Saúde, Brasil.” Rev Panam Salud Publica. 2010; 27(2): 103-9.

[8] Pontes, Fernanda Costa da Cruz de. Investigação de marcadores periféricos alternativos da hiperatividade simpática central em modelo experimental de hipertensão arterial / Fernanda Costa da Cruz Pontes. - Rio de Janeiro, 2012. iv, 48 f. il. ; $30 \mathrm{~cm}$. Dissertação (Mestrado em Biologia Celular e Molecular) Fundação Oswaldo Cruz. Rio de Janeiro, RJ, 2012.

[9] Hering D, Narkiewicz K. "Sympathetic nervous system and arterial hypertension: new perspectives, new data." Kardiologia Polska 2013; 71(5):441446.

[10] Jiang W, Zhang XZ, Gu ML. "Involvement of sympathetic nervous system in the pathogenesis of hypertension". ChineseJournalof Medical Genetics. 2013; 30(5): 565-9.

[11] Pinheiro CHJ, Medeiros RAB, Pinheiro DGM, Marinho MJF. "Modificação do padrão respiratório melhora o controle cardiovascular na hipertensão essencial.” ArqBrasCardiol. 2007; 88(6): 651-659.

[12] Neta NMA, Gomes MAM, Kanashiro CA, Miranda CC, Paiva AMG, Sampaio DL, Aragão LG. "Análise do índice de amplificação sistólico em pacientes acima de 55 anos utilizando atenolol associado ou não a diurético.” Rev Bras Cardiol. 2012; 25(1): 35-40.

[13] Task Force of the European Society of Cardiology and the North American society of pacing and electrophysiology. "Heart rate variability: standards of measurement, physiological interpretation and clinical use”. Circulation. 1996; 93: 1043-65.

[14] Cambri LT, Fronchetti L, De-Oliveita F., Gevaerd MS "Variabilidade da freqüência cardíaca e controle metabólico". ArqSannyPesq Saúde. 2008; 1(1): 72-82.

[15] Vanderlei LCM, Pastre CM, Hoshi RA, Carvalho TD, Godoy MF. "Noções básicas de variabilidade da frequência cardíaca e sua Aplicabilidade Clínica”. RevBrasCirCardiovasc. 2009; 24(2): 205-217.

[16] Virtanen R, Jula A, Kuusela T, Helenius H e Voipio-Pulkki LM. "Reduced heart rate variability in hypertension: associations with lifestyle factors and plasma renin activity.” Journal of Human Hypertension. 2003; 17: 171-179.

[17] Neumann SA, Jennings JR, Muldoon MF, Manuck SB. "Whitecoat hypertension and autonomic nervous system dysregulation." AJH. 2005; 18: 584-588.

[18] Prakash E Sankaranarayanan, Madanmohan, Sethuraman KR, Narayan SK. "Cardiovascular autonomic regulation in subjects with normal blood pressure, high-normal blood pressure and recent-onset hypertension.” Clinical and Experimental Pharmacology and Physiology. 2005; 32: 488-494

[19] Schroeder EB, Liao D, Chambless LE, Prineas RJ, Evans GW, Heiss G. "Hypertension, blood pressure, and heart rate variability. The Atherosclerosis risk in communities (ARIC) study". Hypertension. 2003; 42: 1106-1111.

[20] Ruediger H, Seibt R, Scheuch K, Krause M eAlam S. "Sympathetic and parasympathetic activation in heart rate variability in male hypertensive patients under mental stress". Journal of Human Hypertension. 2004; 18: 307-315.

[21] Takagi T, Ohishi M, Ito N, Kaibe M, Tatara Y, Terai M, et al. "Evaluation of morning blood pressure elevation and autonomic nervous activity in hypertensive patients using wavelet transform of heart rate variability”. Hypertens Res. 2006; 29(12): 977-987.

[22] Fagard RH, Stolarz K, Kuznetsova T, Seidlerova J, Tikhonoff V, Grodzicki $\mathrm{T}$ et al. "Sympathetic activity, assessed by Power spectral analysis of heart rate variability, in white-coat, masked and sustained hypertension versus true normotension". Journal of Hypertension. 2007; 25: 2280-2285.

[23] Pavithran P, Madanmohan MD, RajMithun MBBS, Mathew Jomal MBBS, Nandeesha HMD. "Heart rate variability in middle-aged men with new-onset hypertension.” Ann Noninvasive Electrocardiol 2008; 13(3): 242-248.

[24] Karas M, Larochelle P, LeBlanc RA, Dubé B, Nadeau R, Champlain J. "Attenuation of autonomic nervous system functions 
in hypertensive patients at rest and during orthostatic stimulation.” The Journal of Clinical Hypertension. 2008; 10(2): 97-104.

[25] Maule S, Rabbia F, Perni V, Tosello F, Bisbocci D, Mulatero P, Veglio F. "Prolonged QT interval and reduced heart rate variability in patients with uncomplicated essential hypertension." Hypertens Res. 2008; 31(11): 2003-2010.

[26] Havlicekova Z, Tonhajzerova3 I, Jurko Jr A, Jesenak1 M, Durduki P, Nosali S et al.. "Cardiac autonomic control in adolescents with primary hypertension.” Eur J Med Res. 2009; 14(Suppl. IV): 101103.

[27] Czarnecka D, Posnik-Urbanska A, Kawecka-Jaszcz, KolasinskaKloch W, Wojciechowska W, Fedak D. "Indices of autonomic nervous system activity in women with mild hypertension in the perimenopausal period”. KardiologiaPolska 2009; 67: 243-51.
[28] Bajkó Z, Szekeres C, Kovács KR, Csapó K, Monar S, Soltész P, et al. "Anxiety, depression and autonomic nervous system dysfunction in hypertension". Journal of the Neurological Sciences. 2012; 317(1-2): 112-116.

[29] Celik A, Koç F, Kad H, Ceyhan K, Erkorkmaz U. "Inflammation is related to unbalanced cardiac autonomic functions in hypertension: an observational study". AnadoluKardiyolDerg. 2012; 12:233-40.

[30] Guimaraes, Guilherme Veiga; Belli, Juliana Fernanda Canhadas; Bacal, Fernando and Bocchi, Edimar Alcides. "Comportamento dos quimiorreflexos central e periférico na insuficiência cardíaca”. Arq. Bras. Cardiol. 2011;96(2): 161-167.

[31] Gunes, Yilmaz; Guntekin, Unal; Tuncer, Mustafa and Sahin, Musa. "Os efeitos da trimetazidina na variabilidade da frequência cardíaca (VFC) em pacientes com insuficiência cardíaca.” Arq. B. 